\title{
ШТАМПА О ЕКОНОМСКОМ ПОЛОЖАЈУ ВОЈВОДИНЕ КРАЈЕМ 60-ТИХ И ПОЧЕТКОМ 70-ТИХ ГОДИНА ДВАДЕСЕТОГ ВЕКА ${ }^{1}$
}

Абстаркт: Период од 1967. до 1974. године у Социјалистичкој федеративној републици Југославији обележила је уставна реформа, која је преко три сета амандмана довела до усвајања савезног, републичких и покрајинских устава 1974. године. Овакав развој омогућен је након Брионског пленума 1966. године и учвршћивања политичке позиције снага које су се залагале за принцип „деетатизације“. Уставним променама које су у то време спроведене Војводина је, осим готово потпуне еманципације од републичког руководства, добила могућност и да снажније утиче на одлуке савезних органа. Максимално користећи новостечена права (укључујући и могућност стављања вета), војвођанско руководство је интензивно партиципирало у креирању економске политике, сукобљавајући се често са отпорима републичке, али и савезне власти. Упорно залагање „војвођанских либерала“ за побољшање економског положаја покрајине, пре свега на плану аграра, обележило је крај шездесетих и почетак седамдесетих година прошлог века.

Кључне речи: Војводина, Покрајина, Република, Федерација

Две послератне деценије представљале су време ,релативног привредног заостајања“ Аутономне покрајине Војводине. Док је на нивоу Југославије просечна сттопа раста износила 7,5\%, у Војводини је привредна производња опадала за 9,5\% годишње. После резолуције Информбироа, аграрна политика југословенских комуниста негативно се одразила и на пољопривреду, као главну привредну грану Војводине. Индустријска постројења не само да нису грађена и обнављана, него су из стратешких разлога, пресељавана у друге крајеве Југославије, па чак и у Албанију и у Мађарску. Немачке ратне репарације у потпуности су заобишле Војводину. (Боаров, 2001: 197200) Међутим, половином шездесетих година, војвођанско партијско руководство почело је да са проблемом економског положаја покрајине упознаје савезне и републичке руководиоце, па и самог Тита. 
Осокољени Титовом подршком стеченом у Карађорђеву 1969. године, војвођански руководиоци су наставили да захтевају „општи напор и Републике и Федерације“ у правцу измене претежно аграрног карактера привредне структуре Војводине. (Бјелица, 2014: 133) Међу негативне елементе привредних кретања у Војводини секретар ПК Милош Радојчин је убрајао пад запослености, заостајање личних доходака и велике губитке целокупне покрајинске привреде, а посебно пољопривреде. (Полийика, 21. 5. 1969.) Исте оцене Радојчин је изнео и на седници ЦК СКС, констатујући да је Војводина „данас у релативно тежем економском положају од других делова републике“. Налазећи да сама Покрајина нема средства за радикалније потезе у измени структуре производње, Радојчин се заложио „да се формулише таква концепција развоја Србије, која ће рачунати са великим привредним могућностима Војводине“. Пледирајући за то да Војводина добије приоритетан значај у средњорочном плану развоја целе Републике, унапред је одбацио евентуалне оптужбе да би то значило посезање за нереформским мерама и јачањем улоге државе. „До оваквих токова у привреди Војводине је и дошло због етатистичких тенденција“, завршио је своје излагање Радојчин. (Дневник, 21. 6. 1969.)

Истовремено је покрајинско Извршно веће обавестило јавност да је одбацило одлуку Републичког позајмног фонда о учешћу општина у кредитирању војвођанских студената, будући да је Покрајинска заједница образовања већ плаћала Републичкој заједници образовања надокнаду за школовање студената из Војводине на територији уже Србије. Наиме, пет месеци раније Републички позајмни фонд студената упутио је писмо Скупштинама општина, односно Општинским заједницама образовања на територији Војводине, у коме је затражено учешће у кредитирању студената са територија тих општина. Само једна војвођанска општина је прихватила тај захтев, „мада ни она до сада није склопила уговор“, док је негативан одговор упутило једанаест општинских скупштина. Војвођанске општине су замериле Републичком фонду што их пре доношења такве одлуке није консултовао, те стале иза става да кредитирање и стипендирање студената јесу законска обавеза Републике и Покрајине. За подршку покрајинског Извршног већа одлуци војвођанских општина одлучујућа је било, како је наведено у саопштењу, „чињеница да Покрајинска заједница образовања, једина у земљи, плаћа Републичкој годишње 8 милиона динара“. (Дневник, 13. 6. 1969.)

У исто време, јуна 1969. године, много више буре од питања кредитирања и стипендирања војвођанских студената изазвао је проблем финансирања неразвијених подручја Србије. Скупштина Србије је 1968. године основала Комисију за питање развоја неразвијених подручја републике, са задатком да проучи друштвени и економски положај таквих крајева и да поднесе извештај са предлозима мера које би требало предузети. Комисија је израдила извештај, на основу кога је, почетком априла 1969. године, републичко Извршно веће усвојило своје закључке. Након тога, извештај комисије је 
прослеђен војвођанском Извршном већу, које је располагало и са анализама које су обавили покрајински органи, а које су указивале да Војводина заостаје за развојем националне привреде, па чак и да је „загазила у горке воде неразвијених“, те да „никаква нова захватања и оптерећења привреде и грађана у покрајини не би могла доћи у обзир“. (Дневник, 22. 6. 1969.)

У поменутим анализама су прецизно наведене стопе раста друштвеног прихода за претходни трогодишњи период (1965-1968), по којима је Војводина заостајала и за савезним и за републичким просеком раста. Поновљене су жалбе на застарелу и неконкурентну војвођанску индустрију, која је чак 1968. године забележила пад од $0,3 \%$. Иста је ситуација била и са „стожером војвођанске привреде“ - пољопривредном производњом, коју је уназађивао посебан режим цена, чиме се знатан део националног дохотка преливао у друга подручја Југославије. Наведено је и да су укупне обавезе индивидуалних пољопривредника у Војводини претходне године износиле $22 \%$ од њиховог националног дохотка, а у остатку републике Србије оне су биле скоро упола мање - око $12 \%$. Привредна реформа се негативно одразила и на национални доходак по глави становника, који је у Војводини пре 1965. био за 13,4\% већи од југословенског просека, а 1968. тек за $10 \%$ већи. Опадање броја запослених било је највеће у земљи, па је оно довело до, за оно време, забрињавајућег односа: на десет запослених долазио је један незапослен (пре реформе однос је био 15:1). Животни стандард растао је по стопи од $2 \%$, што је било знатно мање од Југославије $(3,2 \%)$ и Србије $(3,5 \%)$. Просечни лични доходак у Војводини 1968. године износио је 789 динара, наспрам 816 динара у Србији и 853 динара у федерацији.

Са друге стране, Војводина је у 1969. години требало да уплати следеће обавезе: 230,3 милиона динара за буџетску потрошњу; за Ђердап, електроенергетику и инфраструктуру преко 562 милиона динара „од којих се 208 дају неповратно“; у републички фонд за развој неразвијених подручја близу 36 милиона динара. „Цени се да је око 167 милиона динара остало вишка из пензионог и инвалидског осигурања и фонда за додатак на децу, а од тога је привреди Војводине враћено као кредит или инвестиција непуних 17 милиона динара“. Од 27,4 милиона динара, колико је прикупљено на име радио претплате, $45 \%$ је припало Радио Новом Саду, а 55\% Радио Београду, док је целокупна ТВ претплата припала београдском студију (који је од тога издвојио 36 милиона динара за емисије на мађарском). У Фонд за кинематографију (док није био децентрализован) Војвођани су, у претходне две године, уплатили 8,8 милиона динара, а покрајини је од те суме враћена свега једна осмина $-1,1$ милион.

Оно што је највише сметало покрајинском руководству јесте чињеница да су средства која су од Војводине захтевана требало да буду употребљена искључиво за финансирање неразвијених подручја на подручју „уже територије Републике“. Став ПИВ-а, који је образложио његов члан Александар Микић, гласио је „да развој једног подручја не може бити цена смањеног 
развитка другог, поготово ако је и оно сиромашно, а таквих региона у Војводини има“. Подсећајући да је Војводина „и досад битно доприносила развитку мање развијених подручја“" и не спорећи да је неопходно и даље стимулисање напретка таквих региона, Извршно веће је чврсто стајало на становишту да је економски положај покрајине такав „да она тешко може да прихвати предлоге решења о финансирању неразвијених подручја уже Сpбије која би још више оптеретила њену већ иначе осиромашену привреду... Терет неразвијености, према томе, морали би да сносе сви подједнако, а то значи да би решење требало потражити у федерацији. (Дневник, 25. 6. 1969.)

Своје погледе на проблем неразвијених подручја Србије „изван покрајина“" представници Војводине изнели су половином јула 1969. године, приликом расправе у Скупштини Србије. Војвођански посланици су сложно заступали став „да се третман неразвијеног подручја мора одредити у оквирима целе заједнице, а да се средства обезбеде на нивоу федерације“. Стога су одбацивали предлоге за измену Закона о фонду за развој и одлуке о утврђивању недовољно развијених подручја. Са друге стране, посланици из таквих крајева указивали су на чињеницу да се у њиховим општинама погоршало стање од како су 1965. године угашени изворни приходи Републичког фонда за развој недовољно развијених подручја, те да се мора хитно реаговати. Под утиском очигледне поделе на посланике „који потичу из развијенијих и оне који заступају неразвијене комуне“, Скупштина Србије се растала у очекивању октобра и конкретних предлога републичког Извршног већа. (Политиика, 12. 7. 1969.)

Извршно веће Србије је током лета претресало материјал о стању привреде у Војводини и констатовало да она заостаје у свом развоју, налазећи следеће узроке том проблему: неодговарајућа привредна структура Војводине, велики утицај пољопривреде и прехрамбене индустрије, уситњеност одређених индустријских капацитета, нарочито металне, текстилне и дрвопрерађивачке индустрије, спор и неодговарајући процес модернизације индустрије и „можда најважније“ - ниска акумулативност и мала реинвестициона способност покрајине. Председник републичког Извршног већа Миленко Бојанић (иначе Војвођанин) најавио је да ће то тело, заједно са покрајинским Извршним већем, предложити мере за унапрећење привреде Војводине, унапред изразивши бојазан да оне неће бити довољне за решење војвођанских проблема. (Дневник, 23. 8. 1969.)

У међувремену, из Новог Сада је настављено изношење у јавност прецизних података о трајном запостављању војвођанске привреде. Тако је директор Покрајинског завода за друштвено планираање Карло Палић обелоданио да је стопа инвестиција у основна средства у периоду од 1947. до 1964. године била најнижа управо у Војводини - 23,6 (југословенски просек - 28,8; Босна и Херцеговина - 33,3; Црна Гора - 69,7; Хрватска - 24,7; Македонија - 43,9; Словенија - 26,2; Косово - 37,6 и ужа Србија - 27,5). У истом периоду, Војводина је (заједно са Косовом) била последња на скали раста друштвеног 
производа. После привременог успона у прве две године привредне реформе, када је пораст био већи него у Србији и Југославији, „слом је наступио 1967. године“. Истовремено је федерација оптужена да није испунила своју обавезу од $20 \%$ инвестиција у програме Нафтагаса, да нису обезбеђена средства за завршетак канала ДТД итд. Све то довело је Војводину са некадашњег високог положаја на то да буде, како се Палић изразио, „најнеразвијенија међу развијенима, у ствари на граници неразвијених подручја“. (Дневник, 7. 9. 1969.)

Почетком новембра 1969. године Извршно веће Србије је донело Закључке о мойућносииима за бржи иривреgни развој АП Војвоgине, у којима се оцењује да релативно заостајање привреде у Војводини проистиче првенствено из њене структуре, ,, а сви остали узроци долазе у други ред“. Закључено је да би се решење могло постићи бржим развојем индустрије, како би „У догледно време Покрајина добила индустријско-аграрно обележје“. У ту сврху требало је приступити изради „средњорочног плана и дугорочног пројекта привредног развоја Војводине. Веће, међутим, сматра да би требало хитно решити и нека текућа питања, као што су мере у пољопривреди и отклањање неликвидности. Очекује се да ће у склопу општих мера за читаву земљу, предложене мере повољно деловати на привреду ове Покрајине“. (Полийика, 5. 11. 1969.) Тих дана, председник републичке Скупштине Драгослав Марковић је у Новом Саду изјавио да „дугогодишње релативно заостајање Војводине није непознато републичким органима“, а у Београду су се челници РИВ-а на састанку са представницима Покрајине сагласили са „изнетим узроцима успореног раста Војводине“. (Архив Војводине, фонд 334, Записник са седнице Секретаријата ПК СКВ од 10. 11. 1969.)

Све ово очигледно није било довољно да задовољи војвођанске руководиоце, па је покрајинско Извршно веће у децембру одбацило предлог закључака републичког Извршног већа о политици подстицања развоја недовољно развијених крајева уже Србије у периоду до 1975. године, констатујући „да у том документу нису у битним и принципијелним схватањима усвојени ставови и мишљења Покрајинске скупштине, упућени Скупштини СР Србије“. Одбијајући могућност да се средства за тај фонд обезбеде новим пореским захватањима на простору Војводине, покрајинско Извршно веће се сложило да се у ту сврху евентуално употребе „ануитети раније акумулираних средстава такозваног државног капитала, као и део Републичког инвестиционог фонда“. (Дневник, 11. 12. 1969.) Ставове ПИВ-а подржали су и посланици Скупштине Војводине, и то као „крајњи напор Покрајине да у могућој мери изрази разумевање за потребе неразвијених подручја ван аутономних покрајина, иако ће имати реперкусија на успоравање процеса растерећивања привреде у САП Војводине“. Тако обезбеђена средства требало је усмеравати искључиво за инвестиције за основно школство, здравство и основну инфраструктуру (првенствено у путну привреду) - препоручили су посланици војвођанске Скупштине, који су истовремено прихва- 
тили и проследили републичкој скупштини мишљење ПИВ-а о релативном заостајању Војводине и о могућностима његовог превазилажења. (Дневник, 26. 12. 1969.)

Ипак, на последњем састанку у 1969. години, Републичко веће Скупштине Србије усвојило је предлог Закључака о подстицању недовољно развијених подручја у републици ван аутономних покрајина, упркос примедбама посланика из Војводине „да није у складу са системом да се за ову сврху употребљавају средства која се формирају учешћем републике у савезном порезу на промет и чине саставни део буџета, као и из републичког пореза на промет на мало“. (Дневник, 29. 12.1969.) Истовремено су усвојени и Закључци Извршног већа Србије о политици превазилажења заостајања привредног развоја Војводине. На истој седници, потпредседник РИВ-а Бранислав Иконић, у оквиру заједничког експозеа говорио је о проблемима неразвијених подручја уже Србије, али и Војводине и Београда.

Како је у Политиикином чланку насловљеном „Војвођански случај“ прокоментарисано, „Војводина се тако нашла у средини између заосталих јужних општина републике, којима ће се додељивати помоћ из тек основаног републичког фонда за неразвијене и динамичног Београда, који грца у тешкоћама прерастања из признатог административног у конкурентски индустријски центар. То је, могло би се рећи, и место које јој припада - констатовали су тада многи посланици“. Називајући је „подручјем у раскораку“, неименовани коментатор најутицајнијег београдског дневног листа је Војводину описао као подручје које не припада онима „којима је призната несрећна привилегија да уживају повластице неразвијених подручја али очигледно више није ни синоним богатства а још мање темпа и динамике савременог индустријског развоја“. Читаоцима је указано на чињеницу да Војводина постепено уступа своје место при врху листе регионалног распореда националног дохотка у Југославији и како ,још пре десетак година доходак по становнику у Војводини био је за нијансу нижи него у СР Словенији. Сада је већ и СР Хрватска знатно испред Војводине, а и неки други крајеви се постепено приближавају“.

Узроке таквог процеса Полииика је, усвајајући констатације из Иконићевог експозеа, налазила пре свега у првој деценији социјалистичке Југославије, када је „богатој северној Покрајини, како се онда сматрало, припала незахвална улога: да највише доприноси заједничкој државној каси из које су се у разне крајеве сливале инвестиције у нове фабрике и да, у исто време, најмање добија из те касе“. Стога је Војводина остала претежно пољопривредно подручје, суочена са ниском акумулативношћу те привредне гране: „Створени доходак у пољопривреди нижи је него у индустрији, а раскорак цена између брашна и завртња и шећера и пудера - и поред повремених 'усклађивања' - увек се завршавао на штету пољопривредних производа“. Закључци републичке скупштине и Извршног већа, али и Покрајинског завода за друштвено планирање (чија је студија о могућностима развоја 
Војводине до 1975. године у чланку цитирана) слагали су се у потпуности - требало би променити структуру војвођанске привреде, односно омогућити бржи развој индустрије. (Полийика, 21. 4. 1970.)

У Нову 1970. годину војвођанско руководство је ушло охрабрено најновијим подацима о стабилизацији и расту производње, посебно у пољопривреди, смањивању губитака, повећању дохотка и просечних личних примања запослених, односно зато што, по изјави секретара ПК-а Мирка Чанадановића, „у привреди Војводине пробијена је баријера готово трогодишњег заостајања у производњи и запослености“. Ипак, Чанадановић је указао на чињеницу да нису решени најкрупнији проблеми у привреди везани за мере економске политике и да Војводина ,још увек није ухватила корак у кретању напред са Републиком и земљом у целини“. (Политиика, 24. 1. 1970.) Марта месеца посланици Привредног већа Скупштине Војводине подржали су глобалну пројекцију и основне претпоставке развоја покрајине 1971-1975. године, којом је предвиђена стопа раста друштвеног производа од $8,3 \%$ годишње, а потом је исто учинило и Извршно веће Србије.

Интензивнији развој и структуралне промене у војвођанској привреди нашле су своје место и у Среgњорочном йлану развоја Србије, који је припремио Републички завод за друштвено планирање и предочио Извршном већу Србије такође у марту месецу. Међутим, пола године касније, Управни одбор Привредне коморе Војводине је нацрт тог плана одбацио као неприхватљив, будући да је „запоставио регионални аспект развоја привреде, тако да главне привредне области Војводине - пољопривреда, прехрамбена индустрија, петрохемија, нафтна привреда и још неке - нису добиле одговарајуће место. Концепција плана о пољопривреди је непотпуна, неодређена и не одговара њеном значају у укупној привреди. Занемарена је и чињеница да пољопривреда улази у наредни плански период у горем положају него што је била пре доношења садашњег петогодишњег плана. Превазиђене су и концепције према којима развој прехрамбене индустрије доприноси развоју пољопривреде, јер пракса показује обрнут одлив капитала. Чланови овог одбора сматрају, такође, да је неодржива даља оријентација само на реконструкцији војвођанске индустрије, а не и градњи нових капацитета“. (Полиииика, 13. 10. 1970.)

Крај шездесетих и почетак седамдесетих година, у погледу односа републике и покрајине, обележили су и неспоразуми по питању железнице. Статут ЖТП Београд био је тема војвођанске Скупштине, али и Покрајинског одбора синдиката радника саобраћаја и везе 1969. године. (Дневник, 24. 12. 1969.) Како је из Новог Сада замерано, од времена интеграције железничких предузећа драстично су смањене инвестиције у железничку мрежу у Војводини. Обећано је било да ће се то исправити повраћајем амортизације остварене у покрајини, што је предвиђено предлогом новог статута ЖТП Београд, „али је централни раднички савет кориговао члан 190. Статута тако да је испало да је амортизација - неповратна. Када је Статут, по хитном поступку, 
дошао пред Скупштину Србије, посланици из Војводине указали су на ове измене, али без успеха“. ( Дневник, 27. 6. 1969.)

Две године касније, пословање ЖТП Београд у Војводини била је и тема једне седнице покрајинског Извршног већа. Поновљене су замерке на одржавање војвођанских пруга, односно на одливање средстава из доходака и амортизације радних јединица из Војводине. (Дневник, 2. 12. 1971.) Нове протесте у војвођанској скупштини изазвала је, августа 1973. године, најава да ће ЖТП Београд укинути двадесет пруга у Војводини ако му друштвенополитичке заједнице или радне организације не почну да надокнађују губитке који су на њима остваривани. Реагујући на такво условљавање, из Извршног већа Војводине је одговорено на исти начин: „железничари не могу да очекују средства за електрификацију пруге од Инђије до Суботице, а да истовремено немају разумевања и за други део мреже, који не може сваког дана да доноси приходе“. (Политиика, 16. 8. 1973.) Ипак, много више од свих ових различитих републичко-покрајинских несугласица, јавност је узбудио сукоб војвођанске и савезне власти око питања пољопривреде.

Како је небројено пута из покрајинске власти истицано, проблем неликвидности пољопривредне производње оптерећивао је војвођанску привреду дужи низ година, па и деценија. Да је питање пољопривреде од примарног значаја за Војводину био је обавештен и председник Тито у Карађорђеву, који је тада обећао да ће се заложити да се оно што пре реши. Иако се војвођанско руководство почетком седамдесетих дефинитивно определило за убрзану промену привредне структуре (у штампи називану „шок индустријализацију“), пољопривреда је још увек учествовала са $40 \%$ у друштвеном производу покрајине, а прехрамбена индустрија са $23 \%$ у структури индустрије. За Војводину несумњиво најургентнији аспект проблема југословенске пољопривреде (о којој се у то време много расправљало на највишим партијским форумима), било је питање цена аграрних производа, које су у Југославији биле контролисане и држане испод тржишног нивоа. Фебруара 1971. године Данило Кекић, војвођански кадар на челу Одбора Савезне скупштине за пољопривреду, два пута се огласио по том питању. Први пут, на заједничком састанку представника Привредне коморе Војводине и Словеније у Илоку, са изјавом да би цене пољопривредних производа требало слободно формирати, а други пут са констатацијом да су све чланице федерације сагласне да се на нивоу Југославије задржи систем гарантованих цена, али не и којих производа. (Политиика, 17. 2. 1971.)

Упркос сталним напорима, војвођански руководиоци нису успевали да убеде ни органе федерације ни њене чланице да се цене пољопривредних производа значајније повисе. Поред тога, након договора о преношењу економских функција федерације на републике из децембра 1970. године, дошло је до спора између република и покрајина хоће ли од 1. јула 1971. године премије и регреси за аграр бити пренети са нивоа федерације на њене чланице. Јасно је да би укидање савезних субвенција драстично повећало и 
иначе велике губитке војвођанске пољопривреде. И Србија, Македонија и Црна Гора су биле за то да премије и регреси и убудуће остану обавеза федерације, а Хрватска, Словенија и Босна и Херцеговина су биле против. Сматрало се да док не дође до решења тог питања, неће бити могуће ни одредити гарантоване цене пољопривредних производа.

Током пролећа 1971. године одржано је више састанака Савезног извршног већа и његове Координационе комисије, на којима су војвођански преговарачи упорно инсистирали на вишим гарантованим и минималним заштититним ценама пољопривредних производа. Међутим, на последњем састанку, крајем маја на Брионима, невољно су попустили и сагласили се са вољом осталих. Истовремено, постигнут је договор о усвајању савезног Закона о сталним средствима фонда федерације за кредитирање бржег привредног развоја недовољно развијених република и аутономних покрајина, по коме су све републике и покрајине биле обавезне да уплаћују $1,94 \%$ од друштвеног производа у тај фонд. Међутим, на седници Савезног извршног већа, одржаној 16. јула, представник Војводине је ставио вето на тај Закон, који је тада требало формално да буде послат у скупштинску процедуру. На захтев председника СИВ-а Митје Рибичича да се војвођанско Извршно веће поново изјасни о овом случају, оно је 19. јула остало при свом вету. (Дневник, 20. 7. 1971.)

Који су били разлози да Војводина повуче овако неуобичајен потез? Само Покрајинско извршно веће је, у образложењу своје одлуке, подсећало да Војводина није била против доприноса за развој неразвијених подручја, нити је стављала примедбе на висину тог доприноса, него је међу првима прихватила и подржала потребу учествовања читавог југословенског друштва у финансирању развоја неразвијених република и покрајине Косово. Међутим, како би Војводина, као претежно аграрно подручје, могла да прими терет нових обавеза за неразвијене, инсистирала је да се прихвате њени, недавно одбачени, предлози цена пољопривредних производа. На седници покрајинског Извршног већа замерено је и то што се иначе јефтина војвођанска роба не исплаћује на време, него привреда покрајине „потражује данас средства од оних који их имају и који динаре претварају у доларе“. Постојао је још један разлог војвођанског вета, који ПИВ није износило у јавност. Наиме, по старим прописима, средства за помоћ неразвијеним крајевима углавном су се прикупљала преко камате за пословни фонд, коју пољопривреда као грана није плаћала. По новом систему, којим се уместо камате уводио обавезни зајам, војвођанска пољопривреда би била оптерећена. (Политиика, 25. 7. 1971.)

Упорност са којом је Војводина штитила сопствене интересе изазвала је негодовање не само Савезног извршног већа, него и Извршног већа Босне и Херцеговине. Председник тог тела Д. Косовац протествовао је 20. јула у Извршном већу Србије против војвођанског става, оцењујући га као изненађујући за његову републику. Косовац је замолио политичко руководство 
СР Србије да оно пронађе начин да Војвођани усагласе став са осталима како би се 28. јула, за када је било заказано заседање Савезне скупштине, усвојио Закон о фонду за неразвијене, врло битан за Босну и Херцеговину. Са своје стране, председник СИВ-а је сугерисао да би Извршно веће Србије и Извршно веће Војводине могли да се договоре око компензације негативних ефеката спорног Закона унутар СР Србије као целине - што су одбили и једни и други. (АВ, фонд 334, поверљива преписка, 143/1971.)

Ипак, у последњем тренутку, пред саму скупштинску седницу, а након што је Рибичич обећао да ће предложити да Савезна скупштина донесе закључак којим ће СИВ бити обавезан да у октобру изађе пред посланике са анализом положаја пољопривреде и са предлогом конкретних решење за превазилажење неповољне ситуације у којој се нашао војвођански аграр, Извршно веће Војводине је прихватило такав компромис и скинуло свој вето. Спорни закон је усвојен у Скупштини, а иако је изгледало да је Покрајинско извршно веће попустило, у војвођанској јавности је преовлађивало задовољство што је, како је писао Дневник, као ретко када, Војводина „јасно и гласно показала свој став и спремност да га брани уз конкретну одговорност која уз то иде“. (Дневник, 1. 8. 1971.)

Није прошло ни два месеца, а Војводина је опет употребила вето. Овога пута, у питању је био спор око начина финансирања СИВ-а. Шест република и Косово биле су за то да се допринос за издржавање савезне државе израчунава према друштвеном производу укупне привреде, док је Војводина инсистирала да износ треба утврдити према обиму пореза на промет (што је до тада био случај). Овога пута попустило је Савезно извршно веће, па је предложило да Војводина средства за финансирање савезног буџета издваја на основу пореза на промет, а сви остали на основу друштвеног производа. Посланицима Скупштине Војводине, који су безрезервно подржали одлучност ПИВ-а, потпредседник тог тела Сава Филиповић је, у изјави за штампу, на следећи начин образложио разлоге за други војвођански вето: „Да смо прихватили ту основицу наша обавеза савезном буџету била би већа само у четвртом кварталу ове године за преко 70 милиона динара, а годишња за преко 220 милиона... У току разговора око начина будућег финансирања, републике и Косово су изражавале разумевање за овај тобожњи проблем Војводине и тешкоће које она не би могла да савлада одједном. Испољена је спремност да се солидарно поделе 70 милиона па тако, наводно, помогне покрајини. Тиме је створени проблем савезног буџета претворен у тобожњи проблем Војводине. Наравно, ми овакав прилаз нисмо хтели да прихватимо. Још мање смо хтели да примимо понуђену солидарну помоћ која, у ствари, то и није“. ( Дневник, 5. 10. 1971.)

Скупштина СФРЈ је и даље остала у жижи интересовања Војвођана, јер се очекивало да ће Савезно извршно веће, како је у јулу договорено, половином октобра предочити савезним посланицима анализу економског положаја пољопривреде са предлозима мера за решавање њених проблема. Како 
до тога није дошло, Данило Кекић је крајем октобра изразио своје разочарање, тим пре што „ово није први пут да СИВ не извршава своју обавезу према Скупштини када се ради о њеним закључцима о пољопривреди“. (Дневник, 29. 10. 1971.) Посланици из Војводине нису били задовољни оправдањима да је до одлагања дошло због избора новог састава СИВ-а, нити наговештајима да би о теми пољопривреде могло да се расправља у оквиру предлога новог средњорочног плана развоја Југославије. Изражавана је сумња да је прави узрок померања рокова дебате чињеница да ,још нема правих решења или се она до данас нису сагледала“. (Полийика, 9. 11. 1971.) Реаговала је и Привредна комора Војводине, чија су два савета - за задругарство и пољопривреду и прехрамбену индустрију - захтевали од Савезне скупштине да не усваја никакве резолуције о пољопривреди, него да донесе сасвим конкретна решења за побољшање положаја ове гране, као и мере за њен стабилан дугорочан развој.

Коначно је првих дана децембра почела дуго очекивана дебата о пољопривреди у Савезној скупштини. Војвођански посланици су активно учествовали у њеној припреми, упућујући низ конкретних предлога Одбору за аграрну политику Већа народа Савезне скупштине, као и у самом току дебате. Један од њих, уједно и директор ПИК Бечеј, Стеван Ухларик, изразио је задовољство анализом положаја пољопривреде у материјалу СИВ-а, али и замерио што он не садржи никакве конкретне предлоге и мере. По окончању на моменте бурне расправе, посланици су обавезали СИВ да до краја децембра, након консултација са републикама и покрајинама, „предложи политику даљег развоја пољопривреде, донесе оперативне мере за решавање актуелних проблема ове области у оквиру текуће економске политике и припреми биланс потребних пољопривредних производа“. (Политиика, 4. 12. 1971.)

Тек што се окончало скупштинско заседање, дошло је до нове кризе у односима покрајинских и савезних власти - Служба друштвеног књиговодства је блокирала све рачуне САП Војводине због тога што она није на време измирила своје обавезе према федерацији. Налог за ову, иначе прву блокаду рачуна Покрајине од њеног настанка, дао је Савезни секретаријат за финансије, а извршена је због два неизмирена рачуна. Радило се о 13 милиона динара, колико Војводина није уплатила у фонд за неразвијена подручја, и о 41,8 милиона динара дуга за отплату иностраних зајмова и кредита. Покрајински секретар за финансије Душан Влатковић је неизмиривање тих обавеза правдао чињеницом да Југословенска пољопривредна банка и друге савезне банке нису редовно извршавале своје обавезе према Војводини у преношењу припадајућег дела средстава после децентрализације функције федерације. Најавио је и да ће Извршно веће Војводине хитно захтевати од СИВ-а, односно његовог надлежног међурепубличког комитета, званично тумачење права располагања средствима која су после доношења закона о ванбуџетском билансу федерације пренета на републике и покрајине. (Дневник, 11. 12. 1971.) 
У новој 1972. години настављене су несугласице Војводине и федерације око положаја пољопривреде. Почетком јануара из Савезног завода за план је најављено да ће у оквиру Нацрта резолуције о основама друштвено-економске политике у 1972. години пољопривреда добити адекватно место, „максимално у складу са познатим захтевима САП Војводине“. Међутим, покрајински секретар за пољопривреду Милан Јањетовић је изразио своје резерве према оваквом решењу, слутећи да ће „уследити само делимична поправка положаја пољопривреде. А то није оно што је Војводина захтевала“. (Дневник, 9. 1. 1972.) Ипак, половином фебруара из СИВ-а је саопштено да je, након што су на седници његове Координационе комисије усаглашени ставови република и покрајина о свим отвореним питањима средњорочног плана и друштвено-економске политике у 1972. године, усвојен предлог Резолуције о основама политике друштвено-економског развоја у 1972. години. Одмах потом, на седници Председништва СКЈ су усвојени Закључци о остваривању резолуције Прве конференције СКЈ о аграрној политици, којима се утврђују следећи задаци: „донети међурепублички споразум о заједничкој дугорочној политици развоја агроиндустријског комплекса и постићи споразум у току 1972. године о основним дуготрајним решењима у привредном систему и економској политици за ову област“. (Полииикка, 14. 4. 1972.)

Док су савезни државни и партијски органи размишљали о средњорочном и дугорочном развоју пољопривреде, из Војводине је покренуто једно конкретно и акутно питање - питање премија за млеко. Отварање дебате о проблемима производње млека Извршно веће Војводине је предложило покрајинској Скупштини још у новембру 1971. године, са намером да се, у сарадњи са Црном Гором и Косовом, издејствује прелазак са премирања производње на премирање потрошње млека. (Полиииика, 24. 11. 1971.) Разлоге војвођанског незадовољства по питању млека навео је, фебруара 1972. године, Милан Јањетовић. По његовим речима, након што су крајем 1971. године укинуте савезне премије и регреси за млеко, Војводина би, уколико би сама регресирала производњу млека, заправо поклањала три четвртине премија другима „зато што се од 120 милиона литара млека у Војводини, које се ту откупи, потроше само 30, а 90 се пласира на београдско и словеначко тржиште“. Тврдећи да је слична ситуација и са другим пољопривредним производима, те понављајући тезу да се из војвођанске пољопривреде прелива доходак у друге гране привреде, Јањетовић је захтевао јединствену развојну политику за најважније пољопривредне производе на нивоу Југославије. (Политиика, 9. 2. 1972.)

У писму председнику СИВ-а Џемалу Биједићу маја 1972. године, са седнице посвећене приликама у сточарству, покрајинско Извршно веће га је упознало са чињеницом да је „кулминација тешкоћа у области сточарства“ настала крајем 1971. године, кад је престала да важи одлука о премијама и минималним ценама откупа млека од стране савезних органа, и да од тада 
републике и покрајине различито премирају и никако да се договоре о уједначавању. Извршно веће Војводине је још нагласило „да очекује иницијативу СИВ-а за остваривање закључака Председништва СКЈ о постизању међурепубличког договора о основним дугорочним решењима у привредом систему и економској политици у области пољопривреде“. (Дневник, 10. 5. 1972.) У исто време, ПИВ је израдило свој предлог ставова за споразум република и покрајина о дугорочним основама аграрне политике.

Почетком јуна у Карађорђеву су се састали републички, покрајински и савезни секретари за пољопривреду. Осим разматрања дугорочне политика развоја пољопривреде Југославије, била су отворена и нека конкретна питања, од којих је питање млека било најважније за Војводину. Она је захтевала да се постигне такав међурепублички договор којим би се створио фонд за премирање производње млека на нивоу федерације - путем заједничког алиментирања потребног новца наплаћиваног по принципу учешћа појединих региона у потрошњи млека. Представник Војводине је упозорио да ће, уколико се договор у најскорије време не постигне, та покрајина покренути спор пред Уставним судом Југославије. (Дневник, 9. 6. 1972.) У другој половини јуна СИВ је донело одлуку о новим гарантованим ценама пољопривредних производа, којима у Извршном већу Војводине нису били у потпуности задовољни. Незадовољни новим ценама, али и недовољном енергичношћу представника ПИВ-а приликом преговора о ценама били су посланици војвођанске Скупштине. На замерке што није и по трећи пут искоришћен вето, председник Извршног већа Војводине Фрања Нађ је одговорио: „Ми мислимо да смо били довољно енергични. А они са којима смо се договарали и споразумевали сматрају чак да смо били и превише енергични“". (Дневник, 29. 6. 1972.)

Уочи предстојећих разговора република и покрајина о дугорочним основама аграрне политике, представници покрајинског Извршног већа представили су, почетком јула, свој план у седам тачака на седници Секције војвођанских посланика свих већа Савезне скупштине. Кључна тачка тог предлога било је искључивање интервенције република и покрајина, као мере која је директно противречила јединству југословенског тржишта. Извршно веће Војводине је, крајем августа, подржало Акциони програм СИВ-а за спровођење закључака о привредним кретањима, указавши ипак да у склопу тог програма треба не само утврдити потребу доношења договора република и покрајина о развојној политици у пољопривреди, него и одредити рок његове реализације. Такође, затражено је да СИВ до краја септембра, односно пре почетка припремних радова за јесењу сетву, одреди нове заштитне цене. Објашњавајући у то време председницима општинских конференција ССРН Војводине активности своје администрације у погледу аграра, Фрања Нађ је рекао: „Ако неко мисли да Војводина диже само два прста кад се у федерацији говори о проблемима пољопривреде - то је више 
резултат неадекватног интерпретирања наше активности путем средстава јавног информисања“. (Политиика, 5. 9. 1972.)

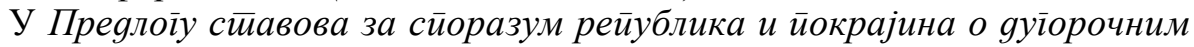
основама аїрарне йолитиике, који је у септембру саставило војвођанско Извршно веће, изнета је прилично песимистичка процена да, чак и уколико се изађе у сусрет свим захтевима пољопривредника, стопа раста производње у наредним годинама неће моћи да прати стопу раста потрошње пољопривредних производа. Конкретно, наведено је да уколико би се постигао споразум о дугорочним основама аграрне политике, дефицит би порастао за 180 милиона долара, а кад не би био постигнут, за око 650 милиона долара. (Политиика, 23. 9. 1972.) Основни принцип који је Војводина предлагала био је да се партиципација додатних средстава одређује на основу рачунице колико је где потрошено пољопривредних производа.

Током октобра, када је дошло и до новог неспоразума међу републикама и покрајинама по питању цена хлеба (Војводина и Србија су тражиле поскупљење ове основне животне намирнице, а остали су били против), све чланице федерације су се обавезале да ће до краја 1972. године постићи споразум. Коначно, на самом крају 1972. године Савезни секретаријат за пољопривреду и Савезни завод за план израдили су материјал на коме је требало да се заснива договор република и покрајина о јединственој аграрној политици до 1975. године. На седници Комисије ПК СКВ за пољопривреду и село подржан је тај материјал у начелу, али тек као неко минимално решење и основа за даље разговоре о аграру. (Дневник, 4. 1. 1973.) Са своје стране, Извршно веће Војводине је изнело неке примедбе на материјал: „заједнички утврдити биланс најважнијих пољопривредних производа; креирати јасну економску политику која би омогућила раст од 2-3\% годишње; обухватити и прехрамбену индустрију у материјалу и млеко уврстити у главне производе од значаја за земљу, чиме би цене и премије постале бриге федерације“. (Полий ика, 7. 2. 1973.)

Будући да је дуго најављивани договор о аграрној политици каснио три месеца, чланови ПИВ-а су крајем марта упознали посланике Скупштине Војводине са разлозима застоја у међурепубличким преговорима. Посланицима је отворено саопштено да су тачке спотицања проблем проширене репродукције (тј. заједничког обезбеђивања средстава) и политика цена, односно њихов недопустиво низак ниво. Решавањем питања цена и премија, како су обавештени војвођански посланици, представници Покрајине су условили своју сагласност на документе чије се усвајање очекивало. Упркос свему, Извршно веће Војводине је изразило оптимизам да ће, упркос свим тешкоћама и обртима, споразум ипак бити постигнут. (Дневник, 1. 4. 1973.)

Након што је пробијен и рок од 15. априла, који је СИВ поставило републикама и покрајинама да постигну договор о даљем развоју пољопривреде, коначно је, у јуну 1973. године, од стране свих прихваћен и последњи, најспорнији од три документа који су се тицали аграрне политике ( Ocнове $\bar{u} о-$ 


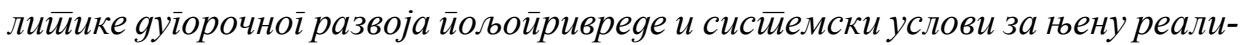
зацију, Сисииемска решења за реализацију йолийике развоја йољойривреgе 1973-1975.' и Зајеgничке основе за йроширену рейроgукцију у йољойривреgи

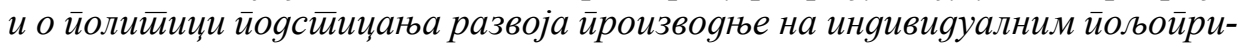

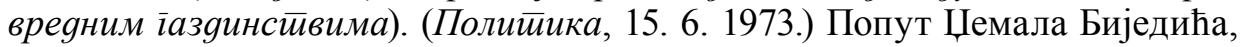
ликовали су и представници војвођанских власти, тврдећи да су примедбе Покрајине у највећој мери биле укључене у поменуте документе, те да је победила њихова идеја о неминовности јединствене аграрне политике на нивоу Југославије.

\section{SUMMARY}

\section{THE ECONOMIC STATUS OF VOJVODINA IN THE LATE 1960S AND THE EARLY 1970S}

The concept of industrialization of Yugoslavia, resting on the development of basic industry and the conflict with the Cominform countries has an adverse economic impact on Vojvodina, making it an area void of investments and leading to a mass transfer of its industry to other parts of the country. Although involved in devising some of these measures, particularly the crop purchase and collectivization, Vojvodina's leadership demonstrated to a certain extent understanding when judging those times, and evaluated the policy then pursued as a consequence of necessity. The articulation of economic interests of Vojvodina has began as early as 1969 in the area of agriculture, revival of the food-processing industry and its further development. The policy was, at the beginning of the 1970s, in conflict with the interests of Serbia and Yugoslavia.

\section{ИЗВОРИ:}

Архив Војводине, Нови Сад, фонд 334 - Покрајински комитет СК Војводине. Дневник, Нови Сад (1968-1974). Полийика, Београд (1968-1974).

\section{ЛИТЕРАТУРА:}

Биланџић, Д. (1979). Хисторија СФРЈ - главни процеси. Загреб: Школска књига Бјелица, С. (2014). Разговор Јосипа Броза Тита и руководства АП Војводине 1969. године. Војвођански простор у контексту европске историје, 2, 133-142.

Боаров, Д. (2001). Политичка историја Војводине. Нови Сад: Europanon consulting. Кончар, Р., и Боаров, Д. (2011). Стеван Дороњски - одбрана аутономије Војводине. Нови Сад: Музеј Војводине.

Петровић, Н. (2015). Социјалистички преображај села. Сремски Карловци: Каирос. Поповић, Д. (2006). Летопис о Влаовићима. Нови Сад: Агенција МИР. 